\title{
Breeding sunflower cultivars for the northern latitudes
}

\author{
WALTER DEDIO \\ Agriculture Canada \\ Research Station, Box 3001 \\ Morden, Manitoba, Canada. ROG IJO
}

\begin{abstract}
Development of short season sunflower hybrids has been the main objective of the Canadian sunflower breeding program. A gene pool created with 50 lines extracted from USSR open-pollinated varieties provided a good source of early inbred lines. The gene pool produced the lines CM447, CM469 and CM497 which were the basis for the superior early parental lines. Another early line, CM594, was extracted from Armavirec. CM447 and CM594 were converted to the cytoplasmic male sterile $(\mathrm{cms})$ form, while CM469 and CM497 were used in the development of fertility-restorer lines. Hybrids from these lines and in combination with HA301, HA232, and NS39 resulted in up to 15 days earlier maturity than the standard hybrids, with good oil content, disease resistance and lodging resistance. An early dwarf hybrid, Sunwheat, developed by SeedTec shows good performance in late seeded tests, but it requires higher plant population and a narrow row spacing.
\end{abstract}

Index words: sunflower, early hybrids, male-sterile forms, restorer lines, dwarf hybrid

\section{Introduction}

The sunflower crop (Helianthus annuus L.) is rather late maturing, usually requiring over 120 days to reach physiological maturity. Often the crop is not ready for harvesting before there is snow on the ground with subfreezing temperatures. In Canada the cultivation of sunflowers has been limited to southern Manitoba in the prairies, where growing degree days above $5.5^{\circ} \mathrm{C}$ are at least 1400 for the period May 1 to Sept 30 .

Considerable variability in maturity require- ment exists in the sunflower germplasm. This has been exploited by the Soviet breeders who through their extensive breeding program developed cultivars that are suitable over a wide area in their country. Some of the cultivars mature up to 14 days earlier than the popular Peredovik. Some early cultivars such as Krasnodarets, Saliut, Armavirec and Chernianka 66 have been licensed for production in Canada.

Open-pollinated cultivars are fairly heter- 
ogenous, thus the maturity is uneven, resulting in delayed harvesting. With the discovery of the cytoplasmic male sterility-fertility restorer system (LECLERQ, 1971), it has become possible to obtain genuine hybrids that are more uniform in maturity and yield considerably more than the open-pollinated cultivars. With the hybrids it was also easier to incorporate disease resistance. With this system we have established a program of developing early maturing hybrids that could extend sunflower production beyond $55^{\circ}$ latitude with less than 100 frost-free days. This manuscript deals with the achievements obtained so far in this program. Results are also presented of tests with a new early dwarf hybrid, Sunwheat, developed and distributed by a commercial company, SeedTec.

\section{Materials and methods}

Most of the sources of early maturity come from the USSR open-pollinated cultivars such as Karlic, Armavirec, Krasnodarets, Tambovsky Early, Saliut and Chernianka 66 . Inbred lines were extracted from these cultivars by selfing for at least 3 generations. Some of these lines had rust (Puccinia helianthi Schw.) resistance incorporated into them early in our breeding program. A gene pool was also established by pooling 50 inbred lines from various sources. Although these lines were selected mostly for superior agronomic characters, some were early. The lines were allowed to interpollinate for 3 generations before being selfed for 3 generations and then selected for desirable types (DEDIO and ENNS, 1976).

From the gene pool, $130 \mathrm{~S}_{3}$ lines were selected, which traced back to $56 \mathrm{~S}_{0}$ plants. These were subsequently tested for their combining ability as males by crossing them onto a cytoplasmic male sterile Krasnodarets. Since the hybrids were sterile, two rows of normal Krasnodarets were planted alternately with two rows of the experimental hybrid in 1974. Krasnodarets supplied the pollen to fertilize the sterile hybrids and was used to compare the performance. From the 130 hybrids, 51 were retested in 1975 .

From the 51 lines, several lines were selected to be converted to the cms or restorer form or to be used to develop other lines. Lines were converted to the $\mathrm{cms}$ form by backcrossing for several generations or were converted to the restorer form by using American restorer line RHA 274 or their restorer composite as a donor of fertility restorer genes. The donor parent also provided the recessive branching character and resistance to certain diseases such as downy mildew (Plasmopora halstedii). Several generations of selfing were required following the cross to obtain the fertilityrestorer and other genes in a homozygous condition. Additional restorer lines were obtained by intercrossing different restorer lines or a restorer line with a normal line to combine the desirable characters.

Combinations of Morden inbreds were evaluated as hybrids. These inbreds were released as germplasm for the use of other breeders (DEDIO and HoEs 1985, 1988). Early inbred lines from United States and Yugoslavia were also evaluated in hybrid combinations with the Morden lines. The foreign lines evaluated were HA124, HA232, HA301 and NS39. The hybrids were tested during the years 1982 to 1987 at a plant population of approximately 50,000 per hectare. Open-pollinated cultivars, Krasnodarets, Saliut and Sputnik were used as checks in 1974 and 1975, while hybrids Cargill 207, and IS 7111 served as checks in 1986 and 1987.

Private breeders have also been involved in breeding of early maturity sunflower hybrids. A new type of early dwarf hybrid, Sunwheat, a sunflower hybrid less than $1 \mathrm{~m}$ in height was released by a commercial company, SeedTec. It was tested at 5 locations in Manitoba in 1986-87 with higher populations of 84,000 plants per hectare as recommended by the company.

\section{Results and discussions}

The average yield of the test hybrids with 
Table 1. Performance of hybrids with Krasnodarets as the tester female parent in 1974.

\begin{tabular}{lcccc}
\hline & $\begin{array}{c}\text { Flowering days } \\
\text { from seeding }\end{array}$ & $\begin{array}{c}\text { Maturity days } \\
\text { from seeding }\end{array}$ & $\begin{array}{c}\text { Yield } \\
\mathrm{kg} \mathrm{ha}^{-1}\end{array}$ & $\begin{array}{c}\text { Oil } \\
\%\end{array}$ \\
\hline Tests hybrids (mean of 130) & 62.5 & 111 & 2230 & 47.6 \\
Krasnodarets & 62 & 111 & 2107 & 45.1 \\
Sputnik & 67 & 116 & 1877 & 45.8 \\
\hline
\end{tabular}

Krasnodarets as the tester female parent was $6 \%$ above the check cultivar Krasnodarets (Table 1). Average maturity was close to that of Krasnodarets. More importantly the oil content averaged 2.5 percentage points above the check cultivar. The retested hybrids yielded $19.6 \%$ higher than Krasnodarets and 17.2 $\%$ higher than Saliut in the 1975 tests (Table 2). Yield increases over Krasnodarets varied from -17 to $45 \%$. The oil content averaged 3.1 percentage points above Krasnodarets and 1.5 percentage points above Saliut.

From the gene pool, three lines were selected that had the best combining ability and were early were coded as CM447, CM469 and CM497. CM447 was released as a female line (DEDIo and Hoes, 1985). Another line, having CM447 in its pedigree, CM597, was also released as a female, (DEDIo and HoEs, in press). CM497 was used to produce the restorer line CM592 (DEDIO and HoEs, 1985). The most promising line has been CM469 from which several restorer lines have been released including CM586, CM587 (DEDIO and HoEs, 1983) and CM590 and CM591 (DEDIo and HoEs, 1985). A cross of restorers derived from CM469 and CM497 yielded an early restorer CM596 (DEDIO and HoEs, in press),

When selections were made from crosses the primary objective was to select for early maturing lines. Several progeny lines were several days earlier than either of the parents. Such was the case with the lines CM591 and CM596.

A trait that is important to sunflower growers all over the world is resistance to lodging. CM469 proved to be a good source of this trait, resulting in the good lodging resistance
Table 2. Performance of hybrids with Krasnodarets as the tester parent, retested in 1975.

\begin{tabular}{lccc}
\hline & $\begin{array}{c}\text { Flowering } \\
\text { days from } \\
\text { seeding }\end{array}$ & $\begin{array}{c}\text { Yield } \\
\mathrm{kg} \mathrm{ha}^{-1}\end{array}$ & $\begin{array}{c}\text { Oil } \\
\%\end{array}$ \\
\hline Test hybrids & & & \\
(mean of 51) & 66.5 & 2899 & 50.7 \\
Krasnodarets & 66.5 & 2425 & 47.6 \\
Saliut & 66 & 2473 & 49.2 \\
\hline
\end{tabular}

of the lines CM590 and CM591. An interesting line, CM595, has been developed by crossing a CM469 derived line with a selection from Krasnodarets. In addition to being early and lodging resistant, it is also dwarf. CM595 has just been converted to the $\mathrm{cms}$ form, but it has been tested for combining ability as a male only.

An early line, CM594 was extracted from an open-pollinated cultivar, Armavirec. It is one of the earliest lines which has good combining ability.

The foreign lines, HA232, HA301 and NS39, also resulted in high yielding, early hybrids. They combined well with the lines CM591, CM594, CM595, CM596 and CM597 (Table 3). Although the yields were lower than widely grown later maturing hybrids in the traditional sunflower area, they were up to 2 weeks earlier in maturity, making them suitable for shorter growing seasons. More testing of the early hybrids is needed.

There was a larger spread in the maturity time in 1987 than in 1986 . This may have been due to cooler September temperatures in 1987. The maturity data reported are physiological maturity, which is the stage where food synthesis in the achene ceases and frosts at this 
Table 3. Performance of early experimental hybrids relative to the means of commercially grown check hybrids Cargill 207 and IS 7111.

\begin{tabular}{lcccr}
\hline $\begin{array}{l}\text { Test } \\
\text { Hybrid }\end{array}$ & $\begin{array}{c}\text { Yield } \\
\%\end{array}$ & $\begin{array}{c}\text { Maturity } \\
\text { Days }\end{array}$ & $\begin{array}{c}\text { Height } \\
\mathrm{cm}\end{array}$ & $\begin{array}{r}\text { Oil Con- } \\
\text { tent \% }\end{array}$ \\
\hline 1986 & & & & \\
CM447 X CM596 & 75 & -9 & -19 & 1.6 \\
HA301 X CM596 & 82 & -7 & -50 & 0.3 \\
NS39 X CM596 & 88 & -9 & -22 & -6.2 \\
HA232 X CM591 & 90 & -4 & -3 & 3.1 \\
CM447 X CM595 & 83 & -5 & -27 & 0.0 \\
1987 & & & & \\
CM594 X CM595 & 78 & -12 & -56 & 0.3 \\
HA232 X CM595 & 79 & -15 & -43 & 3.5 \\
HA232 X CM591 & 89 & -10 & -7 & 2.0 \\
CM594 X CM596 & 70 & -5 & -35 & 1.4 \\
CM597 X CM596 & 66 & -13 & -33 & 2.4 \\
NS39 X CM596 & 88 & & -19 & -7.0 \\
\hline
\end{tabular}

Table 4. Comparison of Sunwheat with check hybrids in 1986-1987 tests in Manitoba, Canada.

\begin{tabular}{lcccc}
\hline Hybrid & $\begin{array}{c}\text { Yield } \\
\mathrm{kg} / \text { ha (SE) }\end{array}$ & $\begin{array}{c}\text { Oil } \\
\%\end{array}$ & $\begin{array}{c}\text { Maturity } \\
\text { Days }\end{array}$ & $\begin{array}{c}\text { Height } \\
\mathrm{cm}\end{array}$ \\
\hline Cargill 207 & $3085(150)$ & 44.0 & 119 & 182 \\
IS 7111 & $2796(287)$ & 49.5 & 116 & 160 \\
IS 7101 & $2621(201)$ & 46.6 & 115 & 165 \\
Cargill 205 & $2613(79)$ & 48.0 & 118 & 169 \\
Sunwheat 101 & $2459(402)$ & 43.3 & 109 & 100 \\
\hline
\end{tabular}

stage would do no harm. For harvesting purposes, however, at least 3 more weeks are required to obtain a moisture content of $10 \%$ or less. The length of the dry-down period varies greatly from one cultivar to another, with some hybrids drying down as much as 10 days earlier if time from flowering is considered.

The performance of Sunwheat throughout the province has been quite variable, but in general it yielded lower than many of the conventional hybrids (Table 4). In contrast to other cultivars where yields declined with a delay in seeding, the yield of Sunwheat increased by an average of $20 \%$ with June 12 and 13 seedings compared to the May 19 and 20 seedings in 1986 and 1987, respectively. Sunwheat is a dwarf cultivar making it less susceptible to lodging. By growing it at a higher population and in narrow rows, the heads are smaller resulting in a faster dry down. The small heads also make it possible to harvest with conventional small grain harvesting equipment.

Other early maturing germplasms from early open-pollinated varieties are available and hybrids that reach physiological maturity in less than 100 days, which is about 20 days earlier than the conventional varieties, have been obtained. Unfortunately, they do not have desirable agronomic characteristics such as resistence to lodging and good yield. Other sources of early maturity are the wild $H$. annuus and other wild Helianthus species. These sources have not yet been exploited. 


\section{References}

Dedio, W. and H. Enns. 1976. Progress Report on breeding for early hybrids. Proc. Sunflower Forum. Jan. 8, 1976, Sun. Assoc. Am. p. 3-4.

- and J.A. HoEs. 1983. Registration of sunflower restorer parental lines CM586 and CM587. Crop Sci. 23: 169 ,

- and J.A. HoEs. 1985. Registration of sunflower parental lines CM447, CM588, CM590, CM591 and
CM592. Crop. Sci. 25: 890.

- and J.A. HoEs. 1988. Registration of sunflower parental lines CM593, CM594, CM596 and CM597. Crop Sci. (in press).

LeClerCQ, P. 1971. La sterilite male cytoplasmique to du tournesol. I. Premieres etudes sur la restauration de la fertilite. Ann. Amelior. Plant. 21: 45-54.

\section{SELOSTUS}

\section{Auringonkukan jalostaminen pohjoisille leveysasteille}

\section{Walter Dedio}

Agriculture Canada Research Station,

Box 3001, Morden, Manitoba, Canada. ROG IJO

Auringonkukan jalostusohjelman pảaatavoite Kanadassa on lyhyen kasvukauden oloihin sopeutuneiden hybridilajikkeiden kehittäminen. Aikaisten sukusiitoslinjojen lähteenä on käytetty neuvostoliittolaisista vapaapölytyslajikkeista valittuja 50 linjaa. Tästä aineistosta polveutuvat linjat CM447, CM469 ja CM497. Aikainen linja CM594 on valittu Armavirec-lajikkeesta. CM447 ja CM594 on mutettu koirassteriileiksi ( $\mathrm{cms}$ ) linjoiksi, kun taas linjoja CM469 ja CM497 käytettiin lisääntymiskyvyn palauttajain, restorerien, kehittämisessă.

Risteyttämällă näitä linjoja keskenään ja ulkomaisten alkuperien HA301, HA232 ja NS39 kanssa saatiin jopa 15 päivăă verrannehybridejă aikaisempia alkuperiä, joiden öljypitoisuus on korkea ja jotka ovat taudinkestäviă ja lakoontumattomia. Aikainen kảăpiő-hybridi Sunwheat, jonka on laskenut kauppaan SeedTec-yhtiō, menestyy hyvin myöhăăn kylvettynă, mutta vaatii tiheăn kasvuston ja kapean rivivälin. 